Article

\title{
Development of Seismic Vulnerability and Exposure Models-A Case Study of Croatia
}

\author{
Gordana Pavić $^{1}$, Marijana Hadzima-Nyarko ${ }^{1} \mathbb{D}$, Borko Bulajić ${ }^{2}$ and Željka Jurković ${ }^{1, *}$ \\ 1 Faculty of Civil Engineering and Architecture Osijek, Josip Juraj Strossmayer University of Osijek, Vladimira \\ Preloga 3, 31000 Osijek, Croatia; gordana.pavic2@gmail.com (G.P.); mhadzima@gfos.hr (M.H.-N.) \\ 2 Faculty of Technical Sciences, University of Novi Sad, Trg Dositeja Obradovića 6, 106314 Novi Sad, Serbia; \\ borkobulajic@yahoo.com \\ * Correspondence: zjurkovic@gfos.hr
}

Received: 20 December 2019; Accepted: 24 January 2020; Published: 29 January 2020

\begin{abstract}
Assessing earthquake risk and building vulnerability requires an exposure model. These exposure models quantify the building stock in terms of structural characteristics, spatial location, and occupancy. The most significant exposure parameters are the structural characteristics of buildings, which must be uniformly covered by structural typologies. Structural typologies that take into account the regional specificities of design and construction provide more accurate and reliable exposure models. Despite the long history of earthquake engineering in the Republic of Croatia, the assessment of exposure and vulnerability of buildings is a rather new concept, hindered by the fact that no city in the Republic of Croatia has a database on the number, types, and characteristics of existing buildings. The article presents the creation of a building exposure model for the city of Osijek, points out the problems and concerns that the realization process brings, and details the practical solutions and strategies that have been used to achieve the set goals.
\end{abstract}

Keywords: earthquake risk; buildings vulnerability; exposure model; structural typologies; buildings database

\section{Introduction}

More than half of the world's population lives in high-risk areas exposed to at least one type of natural hazard: floods, cyclones, droughts, or earthquakes. Earthquakes are one of the most devastating and terrifying natural disasters which a human being can experience, and they can cause almost two-thirds of total annual world economic losses [1-3].

The devastating effects of earthquakes have prompted scientists and the institutions that are responsible for the well-being of society to develop methods and models for predicting, mitigating, responding to, and recovering from its effects. It can be said that risk assessment is a quantitative alternative to preparedness and response to the consequences of an earthquake.

The earthquake risk assessment process combines results of the analyses of seismic hazard, exposed physical and social values, and seismic damage.

Risk can be defined as the probability of damage and consequent loss of a particular state of an element at risk over a given period of time. The human and financial consequences of damages, including injuries and/or deaths, repair costs or loss of income, are the categories that define a loss. The standard defined risk is the probability or likelihood of loss, ranging from zero to one, so it is can be expressed as:

$$
\text { Loss }=\text { Hazard } \times \text { Vulnerability } x \text { Exposure. }
$$

Depending on the purpose and nature of the study, the characteristics of the building or group of buildings being studied, the information available, the appropriate method of assessment (qualitative 
or quantitative), and the organization of data collection and decision-makers, a particular method of a seismic vulnerability assessment is selected [4].

In order to establish a rational basis for risk reduction strategies and to obtain a pre-event vulnerability assessment, the initial step is to identify the relevant parameters of the exposed buildings [5].

Data on social and economic losses from the earthquakes so far show that the most frequent and greatest losses are those caused by the damage and collapse of residential buildings. Therefore, assessment of the expected damage to the existing building stock is an important initial step in the assessment of earthquake risk. Based on that assessment, we can calculate possible dangers to human health and life and corresponding economic losses due to the damage caused. The damage to the existing building stock cannot be estimated without an exposure model.

The exposure model is a detailed database which includes data on structural characteristics and number of buildings according to the adopted typology of structural characteristic. Such a database facilitates rapid estimates of damage and losses to buildings and also enables understanding of the impact of residential buildings on people's lives in the case of natural disasters $[1,5]$.

Although exposure models are extremely important to society, collection of the data that are needed as input for such models is usually not part of established data collection processes [1]. Quantifying apartments stock in terms of structural characteristics, spatial location, or occupancy is a complex process that almost necessarily incorporates doubts and problems that can be successfully addressed only by a systematically elaborated and well-organized methodology [5-7].

This article represents an introduction to the creation of a building exposure model for the city of Osijek. It highlights the problems and concerns that this challenge has brought with it and presents the practical solutions and strategies that have been used to achieve the set goals.

For its development, state-of-the-art methodologies and procedures for collecting building data and mapping them to appropriate structural typologies have been analyzed. The available existing global datasets have been perused and current research on the potential of creating a more reliable and more useful building exposure database has been reviewed.

Best practices and experiences have been adopted and applied in the implementation of the exposure model of buildings in the city of Osijek. This model is still under development and currently includes data on more than 2500 buildings.

\section{Study Area}

\subsection{Seismicity}

The Republic of Croatia is one of the most vulnerable countries in Europe in terms of earthquake risk because it geographically belongs to the Mediterranean-Trans-Asian belt, which has a high level of seismic activity. On the territory of Croatia, from 1850 until 2015, 30,000 epicenters of earthquakes were recorded. Figure 1 shows the epicenters of all of the earthquakes in the region from 1900 to 2017 with $M_{\mathrm{w}} \geq 2.5$ according to the United States Geological Survey (USGS) [8].

In $36.42 \%$ of the territory of Croatia, there is a high risk that an earthquake reaching the eighth or ninth degree on the Mercalli-Cancani-Sieberg scale (MCS) will occur. The earthquake risk zone of seven degrees on the MCS scale covers as much as $56.22 \%$ of the Croatian territory with a population of $1,633,529$, which is more than a third of the total Croatian population. 


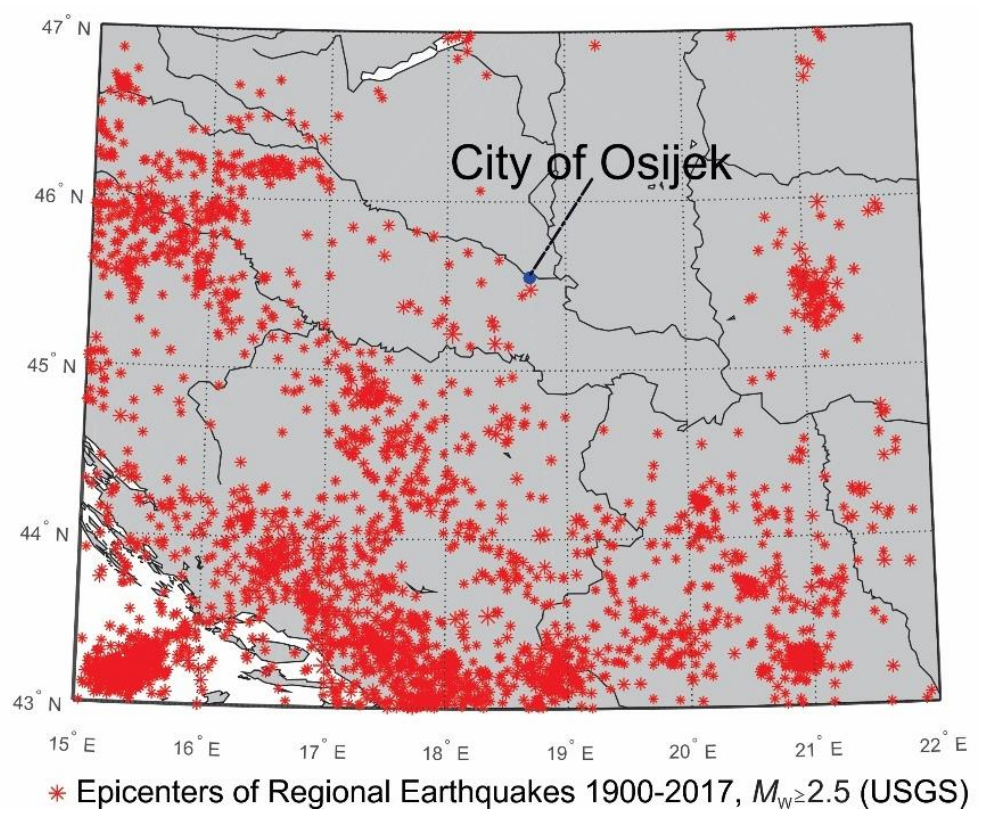

Figure 1. Epicenters of regional earthquakes from 1900 to 2017 according to the United States Geological Survey (USGS) [8] and the location of the city of Osijek.

Osijek is a city located in the east of the Republic of Croatia in an area where tectonic activity is less pronounced. The closest seismic zones to the city are $\approx 30 \mathrm{~km}$ away (Bansko Brdo), and $\approx 70 \mathrm{~km}$ away (Dilj gora). So far, magnitudes of 5.0-5.7 according to the Richter scale have been recorded in these areas, with an intensity in the epicentral region of around VII ${ }^{\circ}$ (MCS).

According to the data from the National Annex to standard EN 1998-1 (HRN EN 1998-1: 2011/NA) [9], the horizontal peak accelerations for the city of Osijek is $0.10 \mathrm{~g}$ for the 475 year return period.

The town is located in a valley by the river Drava, so the geological deposits under it provide loose, sandy, and muddy soil with often high groundwater levels. Several recent studies have shown that such local soil and groundwater features may significantly affect the severity of the surface ground motion during strong earthquakes [10-13]. Seismic microzonation studies in the north-western Balkans [14-18] and a recent study of strong earthquake ground motion in the same region [19] have also shown that deep geological sediments strongly affect the severity of both longer and shorter wave periods. The same studies have shown that in areas with moderate local seismicity but with deep geological sediments, the severity of longer wave periods can be significant during more distant earthquakes.

Therefore, the relatively weak earthquake activity in the Osijek city area should not be a reason to underestimate seismic risks. Even if future studies for the city of Osijek prove that seismic risk due to local seismicity can be neglected compared to some other risks for low rise buildings, regional studies have shown that the deep geological sediments, which are present in the Osijek city area, can affect the behavior of multistory buildings in case of stronger and more distant earthquakes [20,21].

\subsection{Seismic Exposure}

As with many other countries in the world, an important demographic feature of Croatia is the uneven population distribution. Although the average population density is 75.8 inhabitants $/ \mathrm{km}^{2}$, almost two-thirds of 4,284,889 inhabitants in Croatia live in one-third of the country's territory, much of which constitutes urban city areas.

According to the Housing and Population Census from the Croatian Bureau of Statistics in 2011 [22], there are 2,246,910 apartments in Croatia, with a total area of 168,651,195 $\mathrm{m}^{2}$, of which as 
many as 1,912,901 are meant for permanent residence. According to the most recent census, the average number of members per household is 2.87 .

For Croatia, there is undoubtedly a great deal of physical and material exposure to natural disasters, but this is often thought about only after the consequences of a catastrophe. During the collection of the data for the 2011 Census, there was no consideration regarding the potential utility of the gathered data for assessing exposure to earthquake and other natural disasters and for assessing building damage. Available Census data are only partially useful because they do not contain the information on structural characteristics of the existing buildings stock and should be taken into account with caution. The same applies for the collected general data on the year of construction, the number of floors, gross floor area in square meters, etc., as all those Census data do not refer to buildings but instead to individual apartments.

Exposure and damage assessment of buildings in the Republic of Croatia is hampered by the fact that no city in Croatia has a database with information on the number, structural types, and structural characteristics of existing buildings [23].

The first meaningful scientific research, listing and characterization of buildings in Croatia, based on original data and in situ observations, was carried out at the Faculty of Civil Engineering and Architecture in Osijek, as part of the "Earthquake Risk of Urban Areas" project [24-29].

The exposure parameter in terms of structural typologies is also very poorly defined in Croatia. For the assessment of risk due to catastrophic events, so far mostly very rough classifications of up to five structural building typologies have been used. When it comes to disaster prevention and management, the European Union encourages the Member States in the document "European Disaster Risk Management" to develop national approaches and procedures. Depending on the specific structural typology in a particular country or region, design typologies for the area under consideration may be developed.

The complexity of the process of developing an exposure model requires systematically elaborated and comprehensively applicable methodologies, expertise, interdisciplinary collaboration, primarily between structural engineers, architects, and urban planners, and the ability to change and develop it in parallel with working on it.

Exposure models to be generated in Croatia must cover the geographical distribution and major structural characteristics of the building stock, taking into account the observed regional construction properties in order to obtain more reliable exposure models, thereby reducing the adverse effects of earthquakes on buildings and the indirect impacts on human health and lives.

\section{National Building Stock}

\subsection{Characteristics of the National Building Stock}

Despite a long history of earthquake engineering research and development in Croatia (the beginnings of which can be traced to works of Mohorovičić and Kišpatić during the second half of the 19th century), the assessment of exposure and damage to buildings is a fairly new concept in Croatia, whose importance and potential for improvement are discussed on a periodic basis and without a coordinated and elaborated methodology.

A significant stimulus for the development of the methodology for compilation of the buildings stock exposure model was the adoption of EU Directive 2012/27, by which the Republic of Croatia has agreed to adopt the "Long-term strategy to encourage investment in the reconstruction of the national building stock of the Republic of Croatia". The strategy implies, among other things, the development of a National Building Stock database and an overview of the characteristics of those buildings, which should create the basis for obtaining an exposure model of building stock.

The procedure for classifying buildings for the national building stock database should rely on construction materials and specific national construction techniques that are still partially present in contemporary construction. 
There are seven characteristic historical periods with respect to the construction materials and techniques for the buildings of the National Building Stock of the Republic of Croatia (Figure 2a-g):

(1) The period prior to 1940: characterized by construction with traditional techniques and materials (Figure 2a). Unreinforced masonry buildings (URM) were built with brick or stone, and their walls were usually $25-38-51 \mathrm{~cm}$ (brick) and 30-50 cm (stone) thick. Floor structures were generally made from wood beams, or, at the end of the period, of concrete elements (ribbed concrete floors).

(2) Construction period from 1941 until 1970: in addition to the use of traditional techniques and materials, new materials started to be used, such as reinforced concrete (RC), thinner and lightweight structures, structures with large glazed frames (single glazed) (Figure 2b).

(3) Construction period from 1971 until 1980: reinforced concrete structures became thinner and lighter, and the walls were made with minimum structural thicknesses of 16 and $18 \mathrm{~cm}$ (Figure 2c).

(4) Construction period from 1981 until 1987: all available materials on the market were used for construction (Figure 2d).

(5) Construction period from 1988 until 2005: masonry, RC structures, steel, and laminated wooden structures (Figure 2e).

(6) Construction period from 2006 until 2009: the load-bearing structure of the buildings was mostly reinforced concrete (Figure 2f).

(7) Construction period from 2010 until today: all contemporary materials and construction techniques are used (Figure 2g)

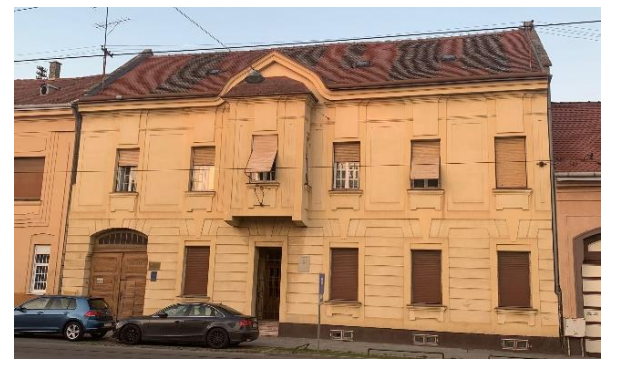

(a) A building built before 1940

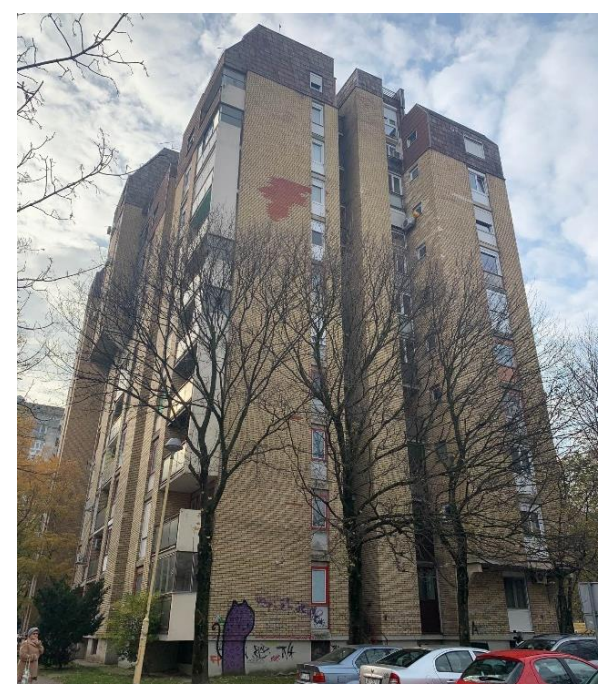

(c) A building built in the period from 1971 until 1980.

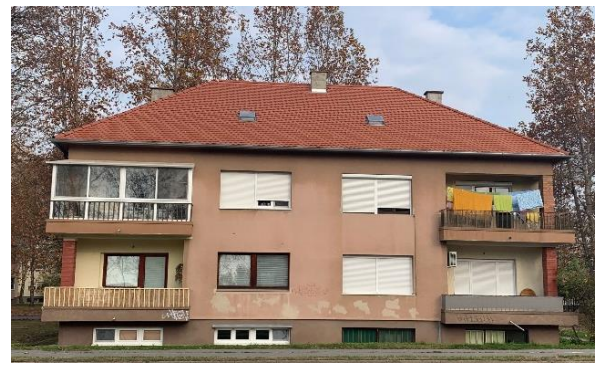

(b) A building built in the period from 1941 to 1970

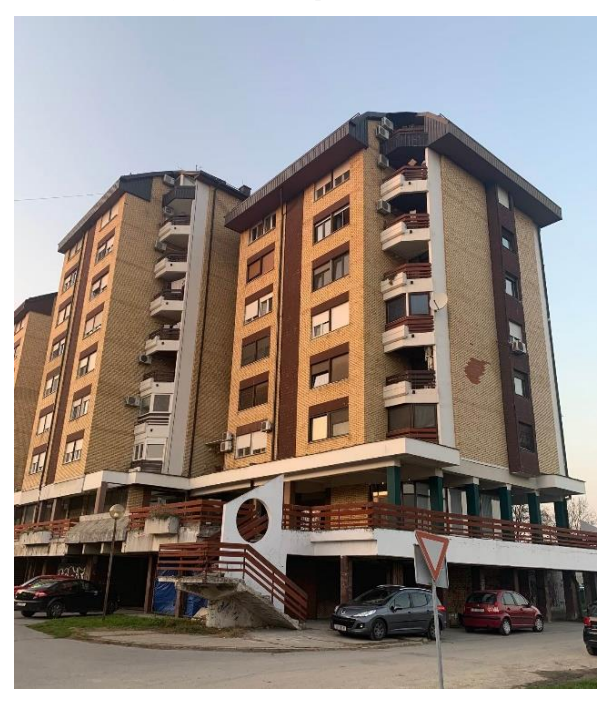

(d) A building built in the period from 1981 until 1987.

Figure 2. Cont. 


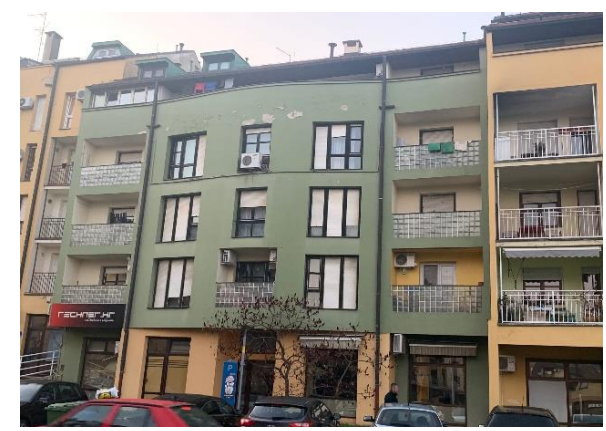

(e) A building built in the period from 1988 to 2005
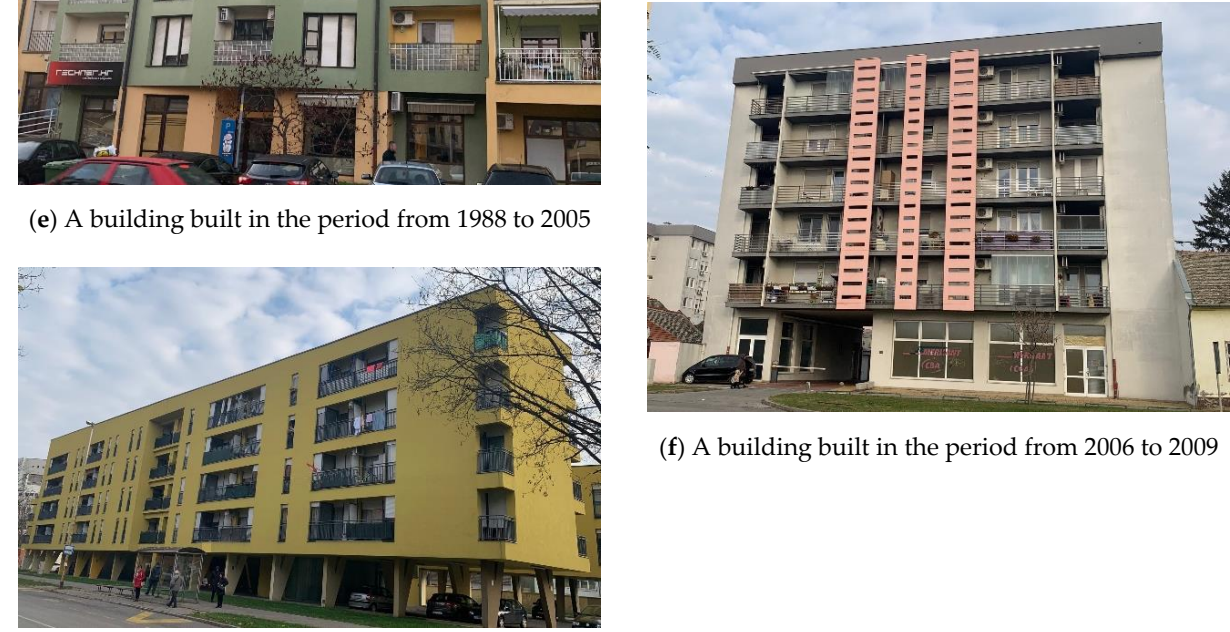

(f) A building built in the period from 2006 to 2009

(g) A building built after 2010

Figure 2. Building types typical for various construction periods: (a) House in Osijek, Gornji grad, before 1940; (b) Building characteristic for the period from 1941 until 1970; (c) Building characteristic for the period from 1971 to 1980; (d) Building characteristic for the period from 1981 to 1987; (e) Building characteristic for the period from 1988 to 2005; (f) Building characteristic for the period from 2006 to 2009; (g) Building characteristic for the period from 2010 until today.

\subsection{Buildings Codes}

Each building code is a set of technical rules whose purpose is to ensure that requirements relating to quality, elasticity, safety, durability, and efficiency are met. Meeting these requirements is especially important when it comes to earthquake safety of buildings, as doing so directly leads to reducing earthquake damage and losses.

Parallel with population growth and the need for new buildings, the need for increasingly reliable building regulations is growing too. Despite being periodically adjusted, the regulations can never predict all possible occurrences, especially when it comes to earthquake activity.

A significant wealth of knowledge about buildings and damage to them was acquired after the largest earthquakes in the last century, especially after the devastating 1963 Skopje earthquake. This knowledge led to the development, updating, and refinement of earthquake regulations and standards [30].

The design and construction of buildings in Croatia are governed by the Construction Act, The Technical Regulation for Building Structures, the Physical Planning Act, and the Law on the Protection and Preservation of Cultural Property.

Until 1948, the design and construction of buildings in Croatia did not apply the regulations related to earthquake resistance of buildings. After the 1963 Skopje earthquake, the first seismic building codes were drafted and later modified. In Croatia, ENV (Eurocode 8, EC8) standards were gradually introduced as pre-standards in the period between 2005 and 2012. Finally, modern EN standards (EC8) were officially put in use in 2011.

The development of the application of building regulations related to earthquake design and construction of buildings in Croatia from 1945 to the present is shown in Table 1. 
Table 1. The application of design codes, characteristics of performance, and earthquake design.

\begin{tabular}{|c|c|c|c|c|c|c|}
\hline & \multicolumn{6}{|c|}{ PERIOD } \\
\hline & Until 1948 & 1948-1964 & 1964-1981 & 1981-2005 & 2005-2012 & 2010-Present \\
\hline $\begin{array}{l}\text { APPLICABLE } \\
\text { STANDARDS }\end{array}$ & $\begin{array}{l}\text { Without a set } \\
\text { of rules }\end{array}$ & $\begin{array}{l}\text { Temporary } \\
\text { technical } \\
\text { standards for } \\
\text { allowed loads for } \\
\text { buildings }\end{array}$ & $\begin{array}{l}\text { Temporary } \\
\text { technical } \\
\text { standards for } \\
\text { construction } \\
\text { in } \\
\text { earthquake } \\
\text { areas }\end{array}$ & $\begin{array}{l}\text { Set of rules on } \\
\text { technical } \\
\text { standards for } \\
\text { construction of } \\
\text { high-rise } \\
\text { buildings in } \\
\text { earthquakes areas }\end{array}$ & $\begin{array}{l}\text { Pre-standards } \\
\text { HRN ENV } \\
\text { 1998-1 (EC 8) }\end{array}$ & $\begin{array}{c}\text { Standards HRN } \\
\text { EN 1998-1:2011 } \\
\text { (EC 8) }\end{array}$ \\
\hline $\begin{array}{l}\text { CHARACTERISTIC } \\
\text { CONSTRUCTION }\end{array}$ & $\begin{array}{l}\text { - URM with } \\
\text { wooden } \\
\text { floors } \\
\text { - from } 1920 \\
\text { RC } \\
\text { structures }\end{array}$ & $\begin{array}{l}\text { - URM without } \\
\text { ties, rigid floors } \\
\text { - RC floors prevail }\end{array}$ & $\begin{array}{l}\text { - confined } \\
\text { masonry } \\
\text { - RC } \\
\text { structures }\end{array}$ & $\begin{array}{c}\text { - confined } \\
\text { masonry } \\
\text { - RC structures: } \\
\text { frames, RC walls, } \\
\text { dual structures }\end{array}$ & $\begin{array}{r}\text { - masonry, RC, } \\
\text { wood s }\end{array}$ & $\begin{array}{l}\text {, steel, laminated } \\
\text { structures }\end{array}$ \\
\hline SEISMIC DESIGN & $\begin{array}{c}- \\
\text { earthquakes } \\
\text { not taken } \\
\text { into account } \\
\text { when } \\
\text { designing }\end{array}$ & $\begin{array}{c}\text { - earthquakes are } \\
\text { taken into account } \\
\text { when designing; } \\
\text { they are } \\
\text { considered as a } \\
\text { force affecting the } \\
\text { top of the building }\end{array}$ & $\begin{array}{l}\text { - first } \\
\text { earthquake } \\
\text { resistance } \\
\text { design codes } \\
\text { - Seismic } \\
\text { map, } 1950\end{array}$ & - simple design & $\begin{array}{c}\text { - complex } \\
\text { design } \\
\text { - increase of } \\
\text { design load }\end{array}$ & $\begin{array}{l}\text {-more complex } \\
\text { design } \\
\text { - further increase } \\
\text { of design load } \\
\text { - seismic map } \\
\text { from } 2012\end{array}$ \\
\hline
\end{tabular}

The reduction of the earthquake vulnerability for new buildings is now taken into account during the process of earthquake-resistant design and their construction.

Existing buildings, especially older ones, cannot be successfully adapted to modern building standards, especially not in the context of constant adaptations and renovations, which often require breaking down large parts of walls.

Although earthquake-resistant building standards are strongly linked to damage and loss assessment, they are often not included in recommendations for strengthening and rehabilitation of existing buildings. However, existing buildings make up a vast majority of the building stock and will generally have the greatest impact on expected losses in the case of future earthquake events.

In addition to the application of earthquake standards for buildings, Table 1 also presents the characteristic structural types and ways of considering earthquake load during the calculation of earthquake resistance of buildings, for given time periods.

\subsection{Classification of Buildings}

The existing classification of buildings by purpose, which was defined by the Ministry of Construction and Physical Planning of Croatia, divides buildings into multi-apartments buildings, family houses, public buildings, and commercial buildings. The Law on Ownership and Other Real Rights defines them as follows:

A multi-apartment building is a building which, as a whole or in more than $50 \%$ of the gross floor area, is intended for residential use and has three or more residential units managed by a building manager (legal or natural person).

A family home is a building in which more than $50 \%$ of the gross floor area is intended for housing and meets one of the conditions: it has a maximum of three residential units and/or gross building area of less than or equal to $600 \mathrm{~m}^{2}$.

Public buildings are the buildings intended for social activities and activities of state units/bodies and organizations, community apartments, and buildings for gathering and activities of the association of citizens and religious communities.

Commercial buildings are those that are private property and where more than $50 \%$ of the gross floor area is intended for business and/or service activities. 


\subsection{Number of Buildings}

The Long-Term Strategy for Encouraging Investments in the Restoration of the National Building Stock of the Republic of Croatia [31] provides an overview of the number of the National Building Stock of the Republic of Croatia. Data are taken from the statistical censuses of the Croatian National Statistical Institute (DSZ RH) and expert estimates on the number of missing buildings in the statistical censuses up to 1952. According to these sources, there are 887,321 buildings in the Republic of Croatia with a total area of 192,519,039 $\mathrm{m}^{2}$. Here, 762,397 buildings are residential (multi-apartments and family homes) with a total area of $142,176,678 \mathrm{~m}^{2}$ [31].

In the residential building category, there are 290,689 multi-apartment buildings with a total area of $55,438,063 \mathrm{~m}^{2}$ (Table 2). This proportion was obtained by calculating the ratio of the number of apartments in the buildings with three or more apartments to the number of all apartments in residential buildings and multiplying the resulting ratio by the total number of buildings constructed [31].

Table 2. Residential buildings in the Republic of Croatia by the year of construction [31].

\begin{tabular}{ccccc}
\hline \multirow{2}{*}{$\begin{array}{c}\text { Year of } \\
\text { Construction }\end{array}$} & \multicolumn{2}{c}{ Multi-Story Buildings } & \multicolumn{2}{c}{ Family Houses } \\
\cline { 2 - 5 } & Number & Area $\left.\mathbf{( m}^{\mathbf{2}}\right)$ & Number & Area $\mathbf{( m}^{\mathbf{2}} \mathbf{)}$ \\
\hline until 1940 & 37,201 & $5,830,983$ & 64,391 & $10,092,805$ \\
$1941-1970$ & 85,595 & $13,473,337$ & 151,507 & $23,747,572$ \\
$1971-1980$ & 59,882 & $10,398,113$ & 93,109 & $16,167,887$ \\
$1981-1987$ & 44,434 & $9,401,527$ & 68,348 & $14,461,473$ \\
$1988-2005$ & 38,358 & $8,177,401$ & 75,615 & $16,120,249$ \\
$2006-2009$ & 18,256 & $6,199,252$ & 13,762 & $4,673,079$ \\
$2010-2011$ & 6600 & $1,957,449$ & 4976 & $1,475,551$ \\
Total & 290,690 & $55,438,062$ & 471,708 & $86,738,616$ \\
\hline
\end{tabular}

The number of family houses is 471,708 with a total area of $86,738,615 \mathrm{~m}^{2}$ (Table 2). However, there is a real possibility that, for example, holiday houses and similar facilities were not taken into account [31].

There is more information on the strategy [31] that is questionable and/or unclear.

From the data presented in Table 2, it follows that the average gross floor area of a multi-apartment building is 55,438,062: $290,690=190.71 \mathrm{~m}^{2}$, which means that such a building would contain on average only $0.80 \times 190.71=153 \mathrm{~m}^{2}$ of net living space or only two apartments of $76.5 \mathrm{~m}^{2}$. It is also unclear whether a building complex consists of multi-apartment buildings, buildings with multiple house numbers or entrances, or it is only one building i.e., only one house number.

There are 124,924 non-residential buildings in the Republic of Croatia with a total area of 50,342,361 $\mathrm{m}^{2}$. Non-residential buildings by purpose are classified as commercial and public; their percentage in the total number of buildings and the area they occupy is shown in Figure 3a,b.

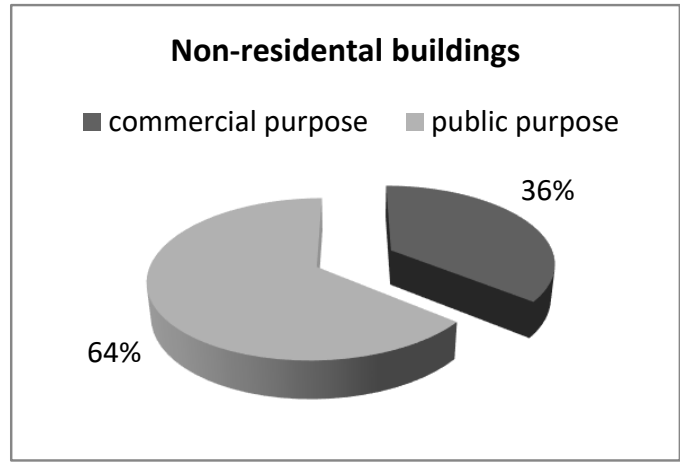

(a)

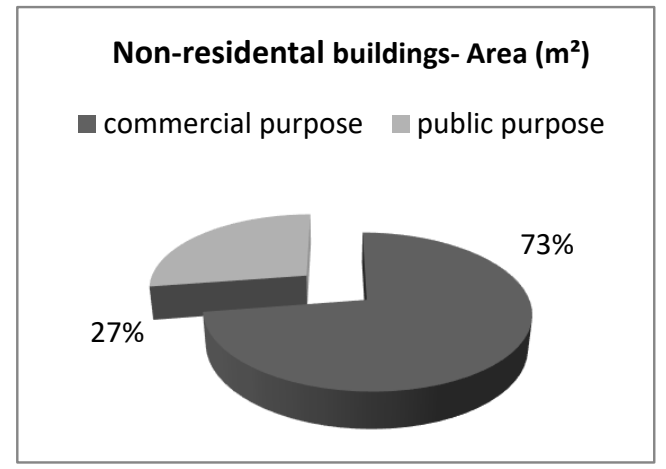

(b)

Figure 3. The non-residential buildings in the Republic of Croatia: (a) percentages regarding purpose; (b) areas. 
In Table 3, non-residential buildings in Croatia are classified by the year of construction.

Table 3. Non-residential buildings in Croatia by the year of construction [31].

\begin{tabular}{ccccc}
\hline \multirow{2}{*}{$\begin{array}{c}\text { Year of } \\
\text { Construction }\end{array}$} & \multicolumn{2}{c}{ Buildings for Commercial Purposes } & \multicolumn{2}{c}{ Public Buildings } \\
\cline { 2 - 5 } & Number & Area $\left.\mathbf{( m}^{\mathbf{2}}\right)$ & Number & Area $\mathbf{( m}^{\mathbf{2}} \mathbf{~}$ \\
\hline until 1940 & 2338 & $1,498,159$ & 12,365 & $1,545,813$ \\
$1941-1970$ & 12,587 & $8,064,602$ & 22,525 & $2,815,845$ \\
$1971-1980$ & 6733 & $5,251,934$ & 19,021 & $1,882,000$ \\
$1981-1987$ & 4323 & $5,108,279$ & 10,158 & $2,152,000$ \\
$1988-2005$ & 10,596 & $8,107,287$ & 11,059 & $2,722,497$ \\
$2006-2009$ & 6199 & $6,352,000$ & 3673 & $2,073,747$ \\
$2010-2011$ & 1952 & $2,158,198$ & 1395 & 610,000 \\
\hline Total & 44,728 & $36,540,459$ & 80,196 & $13,801,902$ \\
\hline
\end{tabular}

The Croatian Bureau of Statistics defines the town as a place with more than 10,000 inhabitants and represents an urban, historical, natural, economic, and social entity. Accordingly, 514,005 buildings in Croatia have a total area of $107,855,294 \mathrm{~m}^{2}$ in the urban areas, and 373,317 buildings with a total area of $84,663,745 \mathrm{~m}^{2}$ exist in the rural areas [22].

In the total building stock of Croatia, 426,071 residential buildings with a total area of 72,419,263 $\mathrm{m}^{2}$ are located in the urban areas and 336,327 buildings with a total area of $69,757,414 \mathrm{~m}^{2}$ exist in the rural areas (Table 4).

Table 4. Overview of the National Residential Buildings Stock in Urban Areas [31].

\begin{tabular}{ccccc}
\hline \multirow{2}{*}{ Territory } & \multicolumn{2}{c}{ Multi-Story Buildings } & \multicolumn{2}{c}{ Family Houses } \\
\cline { 2 - 5 } & Number & Area $\left.\mathbf{( m}^{\mathbf{2}}\right)$ & Number & Area $\left.\mathbf{( m}^{\mathbf{2}}\right)$ \\
\hline urban & 162,454 & $28,237,990$ & 263,617 & $44,181,273$ \\
rural & 128,236 & $27,200,072$ & 208,091 & $42,557,342$ \\
\hline Total & 290,690 & $55,438,062$ & 471,708 & $86,738,615$ \\
\hline
\end{tabular}

Of the non-residential buildings of the National Building Stock, 87,934 buildings with the total area of $35,436,031 \mathrm{~m}^{2}$ are located in the urban areas, and 36,990 buildings with the total area of 14,906,331 $\mathrm{m}^{2}$ exist in the rural areas (Table 5).

Table 5. Overview of the National Stock of Non-Residential Buildings in Urban Areas [31].

\begin{tabular}{ccccc}
\hline \multirow{2}{*}{ Territory } & \multicolumn{2}{c}{ Buildings for Commercial Purposes } & \multicolumn{2}{c}{ Public Buildings } \\
\cline { 2 - 5 } & Number & Area $\left.\mathbf{( m}^{\mathbf{2}}\right)$ & Number & Area $\mathbf{( m}^{\mathbf{2}} \mathbf{~}$ \\
\hline urban & 31,484 & $25,720,860$ & 56,450 & $9,715,171$ \\
rural & 13,244 & $10,819,599$ & 23,746 & $4,086,732$ \\
\hline Total & 44,728 & $36,540,459$ & 80,196 & $13,801,903$ \\
\hline
\end{tabular}

\section{Building Taxonomies}

\subsection{Types of Taxonomies}

There are numerous methods available today for assessing earthquake exposure and building vulnerability. However, the accuracy of these methods depends on the reliability of the information in the corresponding databases. This reliability is based primarily on the unambiguous classification of buildings. To provide a unified classification of buildings in order to adequately describe the building stock, one needs to choose the structural typologies that will cover the various building characteristics in a uniform manner. 
Generally, two types of taxonomies can be employed: specific risk-oriented taxonomies or the faceted taxonomies [32] which have been recently developed. Risk-oriented taxonomies are used for large-scale assessments, and their primary goal is to unequivocally assign damage models to particular buildings. Typological classes of buildings consist of similar structural characteristics, since it is assumed that buildings of similar structural characteristics will have similar behaviors due to earthquakes.

Numerous building taxonomies have been developed in the world and in Europe in recent decades, for use at the regional and global level. They mainly describe and classify buildings according to their earthquake resistance, structural response to earthquakes and earthquake risk assessment. The use of these taxonomies is possible when the exposure models based on in-situ data collection are developed [33] or when credible data (e.g., from a census) and expert judgment are combined [34].

The most comprehensive, risk-oriented classification of buildings globally is the PAGER-STR taxonomy. According to the creators of this taxonomy, any taxonomy is a compromise between simplicity and thoroughness [35]. The PAGER-STR taxonomy contains a total of 103 classes, in which buildings are varied with respect to wall material, height, lateral load resistance, and earthquake design compliance. It was created by merging several pre-existing taxonomies and it was later supplemented with building typologies collected through specific studies in several countries. A taxonomy with so many building classes (103) may be suitable for classification and displaying the number of buildings at the global level. For local studies at state or city level, the number of existing classes is much smaller, and it is even smaller for the group of only residential buildings. It should be noted that the 103 types do not apply, for example, to bridges and other infrastructural structures for which no "taxonomy" has been developed at all.

In the US, it is mainly used for global real-time earthquake loss estimates and earthquake risk analyses.

The Federal Emergency Management Agency (FEMA) introduced the HAZUS taxonomy [36] to quantitatively assess the impact of natural phenomena (earthquakes, storms, hurricanes) on buildings in the United States. This taxonomy was based on the classes of buildings that were proposed by a rapid visual inspection of buildings with the aim of assessing their usable and safety characteristics and their current occupancy. The HAZUS taxonomy contains 36 building typologies, mainly defined by different lateral resistance systems and with four levels of compliance with earthquake-resistant design regulations.

In Europe, the basis for describing the noticeable effects of ground motion on the environment, humans, and the built environment is provided by the European Macroseismic Scale - EMS98 [37]. It was developed due to the need for critical revision of the MSK-64 scale and the scale that preceded it and represents their upgrade. With the aim of recognizing the characteristics and variability of earthquake effects in a modern built environment, the EMS-98 scale contains 15 different classes of buildings, which differ in the material used for the construction of walls and in different structural details pertaining to the levels of earthquake-resistant design. Each building class is characterized by the expected range of physical damage, defined by a six-level scale going from " $\mathrm{A}$ " to " $\mathrm{F}$ ", with " $\mathrm{A}$ " being the most vulnerable. Although the adopted EMS98 classes are representative of building stocks in Europe, the scale is also frequently used in other regions around the globe.

Although it is common to use the taxonomies developed in other geographical environments and not in the analyzed region, this may cause epistemic uncertainties in a later damage model [35].

When it comes to uncertainties, it is also important to have in mind that the whole process of direct classification of buildings into predetermined sets with respect to construction characteristics, is usually carried out by experts whose judgment is subjective and, depending on the skills and experience acquired, may be partially biased.

In addition, by assigning a class, a part of the data on the structural and non-structural features of the observed building is lost. Therefore, each of the taxonomies must allow the classification of buildings to be based on at least basic characteristics for the assumed taxonomy class. This also 
ensures its usability for the calculation of different types of residential building risks and for the need of different stakeholder interests.

In the scope of modeling a new framework to better understand and manage the insurer's roles in catastrophe risk management, Kesete et al. [38] classified residential buildings according to: geographic area unit or location, architectural features (number of floors, type of roof, etc.), and construction characteristics.

A faceted taxonomy is made up of a set of taxonomies, and the task of each taxonomy in the set is to describe a particular domain from a different facet (aspect). This taxonomy is characterized by conceptual clarity, compactness, and scalability, the features that have been identified as deficient in the risk-oriented taxonomies [32,39].

In order to describe and classify buildings in Europe in detail from the structural and functional point of view, a faceted taxonomy is proposed within the SYNER-G project [40], based on 15 aspects or a list of categories.

The Global Earthquake Model (GEM) has developed a comprehensive faceted taxonomy to describe typical building typologies in the exposure models with global scope, based on credible data [6].

In Table 6, the advantages and disadvantages of the risk-oriented and faceted typologies are presented.

Table 6. Advantages and disadvantages of the risk-oriented and faceted typologies.

\begin{tabular}{cll}
\hline TYPOLOGY & \multicolumn{1}{c}{ Advantages } & \multicolumn{1}{c}{ Disadvantages } \\
\hline \multirow{4}{*}{ RISK } & $\begin{array}{l}\text { - predefined typologies } \\
\text { - a combination of credible data, } \\
\text { expert judgment, and in-situ data } \\
\text { collected }\end{array}$ & $\begin{array}{l}\text { - the bias of the resulting models } \\
\text { - can have a limited geographical range: } \\
\rightarrow \text { cannot be easily applied to other regions } \\
\rightarrow \text { epistemic uncertainties in a later vulnerability } \\
\text { model }\end{array}$ \\
\hline \multirow{4}{*}{ FACETED } & $\begin{array}{l}\text { - cannot be used directly to create risk-oriented } \\
\text { exposure models }\end{array}$ \\
& $\begin{array}{l}\text { - the standardized description of } \\
\text { buildings based on a rich set of } \\
\text { basic attributes } \\
\text { - descriptions of various building } \\
\text { typologies on a wide geographical } \\
\text { scale }\end{array}$ & $\begin{array}{l}\text { biased-classification depends on the skills and } \\
\text { experience of the classifier } \\
\text { - after class assignment, most of the information on } \\
\text { the structural and nonstructural characteristics of the } \\
\text { building under consideration is lost } \\
\text { - the assigned class cannot be further modified or } \\
\text { supplemented upon completion of the classification }\end{array}$ \\
\end{tabular}

\subsection{Criteria for Building Taxonomies}

During the data collection phase, a large number of attributes can be observed and recorded. However, most often only a part of these attributes is used for the actual classification of buildings. Namely, at the application stage, most of these data are being rejected by using simplified taxonomies that may not fully capture the properties of a building stock.

The GEM (Global Earthquake Model) provides criteria on which a valid and sufficient elaboration should be based and on which existing elaborations can be evaluated. Through elaboration, one should be able [6]:

(1). to see the differences in the earthquake-resistance characteristics of structures or to distinguish: earthquake resistant structures

variants of earthquake-resistant structures

conditions of structures prior to earthquake reconstruction

conditions of structures after earthquake reconstruction 
ductile structures

non-ductile structures.

(2). to recognize the characteristics that define a particular class of structures (by persons who test the same structural system in the field or use field data) in order to classify a structure in a valid class

(3). to fully integrate all engineering characteristics relevant to the overall earthquake performance of a civil engineering structure in order to capture all earthquake-resistance properties and loss characteristics for the entire building, including structural dimensions and non-structural parts

(4). to ensure simplicity of classifications with as few classes as possible while still meeting other requirements, especially assemblability (ability to combine class groups), while there are still enough resulting combinations to distinguish differences in seismic performance

(5). to involve in classification groups (as much as possible) almost every structural system

(6). to familiarize engineers and architects with the classifications system (so that they could easily and accurately identify structural characteristics) and also with the nomenclature, which should be defined in order to avoid ambiguity

(7). to handle civil work (dams, bridges, tunnels) in the future and include them in the classifications

(8). to ensure applicability to other hazards (floods, hurricanes, and volcanic eruptions) or adaptability to other communities in view of these hazards

(9). to achieve intelligibility, intuitiveness, and ease of use by those who collect the data, by those who organize their analysis, and end-users

(10). to ensure international applicability to any region of the world.

For some of the more commonly used classifications, the GEM provides an estimate of the extent to which each classification satisfies the above requirements (Table 7). SYNER-G has the greatest potential for development with respect to meeting the GEM requirements.

Table 7. Comparisons of structural taxonomies against stated criteria [6].

\begin{tabular}{|c|c|c|c|c|c|c|c|c|c|c|c|c|}
\hline 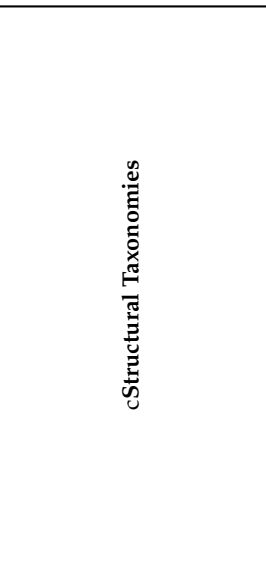 & 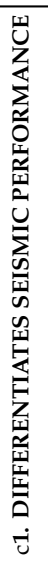 & 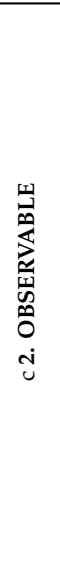 & 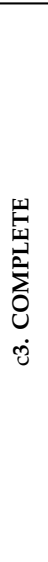 & 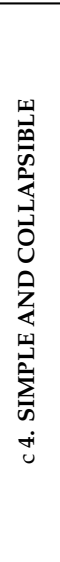 & 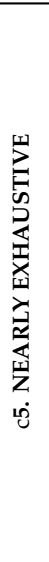 & 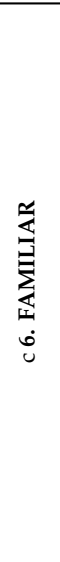 & 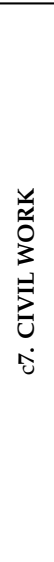 & 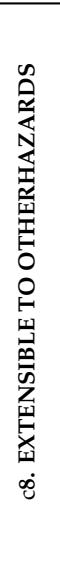 & 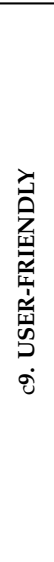 & 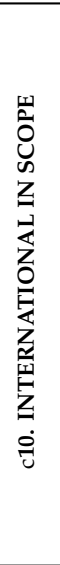 & SCORE & COMMENTS \\
\hline ATC-13 [41] & $\mathrm{s}$ & $\mathrm{s}$ & $\mathrm{s}$ & $\mathrm{s}$ & $\mathrm{u}$ & $t$ & $t$ & $\mathrm{u}$ & $t$ & $\mathrm{u}$ & 10 & California-focused \\
\hline $\begin{array}{c}\text { FEMA } 154 \text { (ATC-21) } \\
{[42]}\end{array}$ & s & $\mathrm{s}$ & $\mathrm{u}$ & $\mathrm{s}$ & $\mathrm{u}$ & $\mathrm{t}$ & $\mathrm{u}$ & $\mathrm{u}$ & $\mathrm{t}$ & $\mathrm{u}$ & 7 & For US construction \\
\hline EMS-98 [43] & $\mathrm{S}$ & $\mathrm{s}$ & $\mathrm{u}$ & $\mathrm{s}$ & $\mathrm{u}$ & $\mathrm{t}$ & $\mathrm{u}$ & $\mathrm{u}$ & $\mathrm{t}$ & $\mathrm{t}$ & 9 & Too broad \\
\hline WHE [44] & $\mathrm{S}$ & $\mathrm{s}$ & $\mathrm{t}$ & $\mathrm{s}$ & $\mathrm{t}$ & $\mathrm{t}$ & $\mathrm{u}$ & $\mathrm{u}$ & $\mathrm{t}$ & $\mathrm{t}$ & 13 & More than structural \\
\hline Coburn and Spence [45] & $\mathrm{S}$ & $\mathrm{s}$ & $\mathrm{s}$ & $\mathrm{t}$ & $t$ & $\mathrm{t}$ & $\mathrm{u}$ & $\mathrm{u}$ & $t$ & $\mathrm{t}$ & 13 & $\begin{array}{l}\text { Both engineered and } \\
\text { non-engineered } \\
\text { buildings }\end{array}$ \\
\hline HAZUS [46] & $\mathrm{T}$ & $\mathrm{s}$ & $\mathrm{s}$ & $\mathrm{s}$ & $\mathrm{u}$ & $\mathrm{t}$ & $\mathrm{u}$ & $\mathrm{t}$ & $\mathrm{t}$ & $\mathrm{u}$ & 11 & For US construction \\
\hline Gunel and Ilgin [47] & $\mathrm{S}$ & $\mathrm{s}$ & $\mathrm{s}$ & $\mathrm{s}$ & $\mathrm{u}$ & $\mathrm{s}$ & $\mathrm{u}$ & $\mathrm{u}$ & $\mathrm{t}$ & $\mathrm{u}$ & 7 & Tall buildings only \\
\hline CEQID [48] & $\mathrm{T}$ & $\mathrm{s}$ & $\mathrm{s}$ & $\mathrm{s}$ & $\mathrm{s}$ & $\mathrm{t}$ & $\mathrm{u}$ & $\mathrm{u}$ & $\mathrm{s}$ & $\mathrm{t}$ & 11 & EQ damage database \\
\hline PAGER -STR [49] & $\mathrm{T}$ & $\mathrm{s}$ & $\mathrm{t}$ & $\mathrm{t}$ & $t$ & $\mathrm{t}$ & $\mathrm{u}$ & $\mathrm{u}$ & $\mathrm{t}$ & $\mathrm{t}$ & 15 & $\begin{array}{l}\text { Most comprehensive to } \\
\text { date }\end{array}$ \\
\hline SYNER-G [50] & $\mathrm{T}$ & $\mathrm{s}$ & $t$ & $t$ & $t$ & $\mathrm{~s}$ & $t$ & $\mathrm{~s}$ & $t$ & $t$ & 17 & Best potential \\
\hline
\end{tabular}




\section{Exposure Model for the City of Osijek}

\subsection{Development of the Exposure Model}

The various census databases and public sources of information on buildings are often inaccessible, incomplete, and made up of data of questionable utility, which are often in unnecessarily different formats. In addition, they neither reveal nor satisfy the essential needs for engineering modeling of building exposures and the risk estimates that could be derived from them.

The goal of developing a building exposure model for the city of Osijek is to produce reliable and useful attribute information that describes the structural and other characteristics of buildings, and which will satisfy the needs for accurate and quality earthquake and other risk assessments for the city of Osijek.

Creating an exposure model means collecting, analyzing, categorizing, and documenting only relevant information about buildings and the physical and social values in them. It is common practice, however, that the aggregate data obtained from basic census parameters from which the estimated risk cannot be reliably calculated for each building are used to estimate the exposure of buildings.

Therefore, the intention of the exposure model is to collect building-level data on only certain, valuable attributes that are most likely (or less likely) related to specific building typologies and that allow for risk calculations for each investigated building, in compliance with one or more typologies of construction.

The initial step in creating an exposure model is to define procedures, shapes, and forms of work, and basic research methods and techniques.

For the exposure model for the city of Osijek, the adoption of a working methodology has been elaborated, which divided the whole process of modeling the exposure of buildings into three steps:

(1) to determine the number of buildings and population, geographical characteristics, structural dimensions, characteristics of the material and of construction methods

(2) defining classification rules and adopting structural typologies

(3) assignment of structural typologies.

In the first step, data are collected on the number of buildings and inhabitants in them, as well as the geographical characteristics, building dimensions, and structural and material characteristics of the buildings. Some structural and material characteristics cannot be collected and will be assessed only with respect to what is known about local construction methods (types of load-bearing structures) and commonly used materials and their properties. Hence, for the assessment of these characteristics, there would be no in situ testing and measurements.

The data are collected in-situ and initially recorded on prepared paper forms, which are then transferred to Excel spreadsheets. In the tables, the data are processed and systematized, thus forming a basic database, which can be constantly updated and modified, and out of which one could extract a number of cumulative and statistical data. Later, a mobile application was developed that facilitated the process of data collection, but also enabled the automatic transfer of data to Excel forms.

For the second step, an algorithm was developed to define the classification rules and adopt the design typologies through 5 levels (Figure 4).

In accordance with the defined classification rules and the adopted design typologies from step 2, in the third step, the design typologies are assigned to the buildings that have been identified and their characteristics listed (in step 1). 


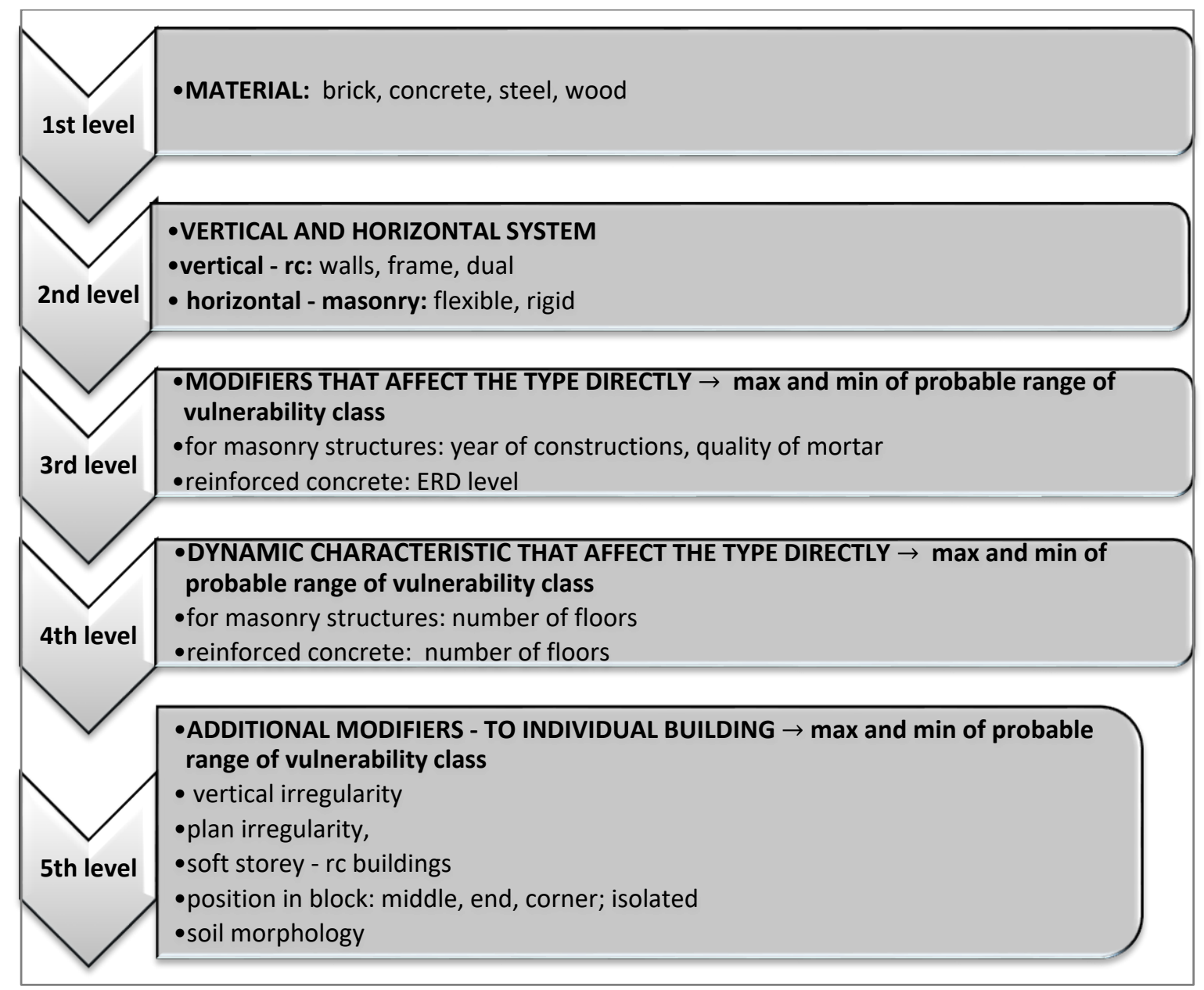

Figure 4. An algorithm for defining classification rules and adopting construction typologies.

\subsection{Attributes for Building Typologies Description}

Evidence from past earthquakes and numerous studies conducted thereafter have shown that some characteristics of a building have more influence on earthquake resistance than others. For example, the influence of the lateral resistance of the structure and the predominant material from which the structure is derived (brick, reinforced concrete, steel, etc.) is very significant.

Reinforced concrete buildings with shear walls, steel frame buildings, and wooden buildings have shown very good performance during past earthquakes. Unreinforced masonry structures and reinforced concrete frames with masonry infills showed the worst earthquake behavior and caused significant human losses during many past earthquakes (Turkey 1999, Taiwan 1999, India 2001).

The Global Earthquake Model (GEM Basic Building Taxonomy v2.0) proposes to adopt the following 13 attributes when developing an exposure model that, alone or in synergy, can significantly influence the earthquake behavior of a building [8]:

(1) Direction: orientation of the building/s with respect to different lateral resistance in the two main horizontal directions of the floor plan/s perpendicular to each other.

(2) The material of the lateral load resisting system (brick, steel, wood, etc.)

(3) Structural system resistant to lateral load: provides resistance to horizontal earthquake forces through vertical and horizontal structural components (wall, moment frame, etc.).

(4) Building height above ground level: number of floors and information on the existence of any basement and the slope of the ground.

(5) Date of construction or retrofit: the year of completion of construction/retrofit. 
(6) Occupancy: the type of activity (function) within the building (residential, business, etc.).

(7) Position of the building in the block: position of the building within the block of buildings (isolated, in a row, on the corner).

(8) Building plan layout (rectangular shape, L-shape, etc.)

(9) Structural irregularities (one floor significantly higher than the others, the irregular shape of the building or alteration of the structural system or material). A building may have more than one irregularity, primary and secondary irregularities can be identified/recognized.

(10) Exterior walls: the material of exterior walls (brick, glass, etc.).

(11) Roof: the shape of the roof, the material of the roof cover, the roof structure and the gable wall.

(12) Floor: floor material, type of floor system and floor-wall connection.

(13) Foundation system: the part of the structure where the base of the building meets the ground.

Many scientists involved in the development of earthquake exposure models agree that the GEM typology has well-defined and described attributes, but they also agree that it is impossible to collect them all in practice. The creators of the exposure model for the city of Osijek have come to the same conclusion and indicate the need to use a certain level of assessment not only because of the unavailability of some data but also in order to avoid the possibility that the data collected may not always be accurate or sufficiently precise.

Taking into account the recommendations of the GEM typology, available data sources, and construction specificities in the city area, the attributes that may be sufficient to develop the exposure model are considered.

Two major attributes have already been mentioned when it comes to earthquake damage to buildings: the material of the load-bearing system and the lateral resistance of the structure with respect to the two main mutually perpendicular horizontal directions of the building floor plan.

The material of the load-bearing system is classified as an attribute for the exposure model of the city of Osijek, however, the orientation of the load-bearing walls is not because it cannot be determined by visual inspection from the outside without available project plans and documentation.

Building height is one of the attributes that determine the dynamic property of the building-the fundamental period of vibration, which can significantly affect the earthquake behavior of a building. Higher buildings are usually more flexible and are characterized by longer vibration periods, however, this does not mean that they will suffer less damage than lower buildings. For the behavior of buildings regardless of the height, the characteristics of the ground and the earthquake itself must be also considered.

The position of the buildings in the block was selected for exposure modeling as an attribute important for vulnerability. Buildings in densely populated urban centers are at risk of being struck by one another, those located at the end of the row are always more prone to damage than the one located in the middle. Namely, seismic dilatations (as air space) between buildings are virtually non-existent, so the theoretically conceived earthquake behavior cannot be realized. There is always a collision of the buildings that are next to each other in the same row, and friction on the surfaces at the junction of the two buildings prevents movement that is perpendicular to the row direction.

One of the most critical characteristics in terms of the expected earthquake behavior of buildings is the presence of structural plan irregularities and/or vertically irregularities.

Earthquake impulse causes complex behavior of irregular structures, especially in the inelastic area. Asymmetry in mass, strength and stiffness distribution, as well as irregularuty in plan, are several of the most common sources of earthquake-induced damages in buildings because they cause translation and rotation of the floors.

Although seismic codes distinguish plan irregularities and vertical irregularities of the buildings, often structural irregularities result from a combination of both types of irregularities [51]. 
Many studies dedicated to a better understanding of the seismic response of vertically irregular structures show that discontinuities of mass, strength, or stiffness in height do not necessarily result in a real increase in plastic requirements and generally poor seismic behavior [51-53].

Studying the devastating earthquakes in the period 1980-2003 and their impact on buildings, Gonzáles and Gómez [54] confirmed that the degree of earthquake-induced damage to a building is strongly related to the presence of structural irregularities in the affected buildings.

The distribution of earthquake forces in a building is affected by the type of roof and floor. that is the type of diaphragm (rigid or flexible in its own plane). Buildings with rigid diaphragms have higher earthquake resistance and better behavior than buildings with flexible diaphragms, however, such buildings usually have a heavier roof/floor structure that often exhibits worse earthquake behavior, regardless of the type of load-bearing horizontal system and its material.

Attributes such as occupancy, non-bearing exterior walls, date of construction or reconstruction do not have a direct impact on the expected earthquake behavior of a building, but rather provide a source of relevant information for determining other attributes or are used for final analyses and evaluation. Building occupancy information, for example, can be used to estimate seismic risk in terms of the number of deaths or injuries.

For the city of Osijek exposure model, the following attributes have been adopted that will best describe the analyzed buildings [29]:

- $\quad$ building location information: address, cadastral number

- $\quad$ the position of the building in relation to the particular city block or street

- general information: the purpose of the building, the year of construction and/or reconstruction (if any), and the number of persons living in the building.

- $\quad$ information on the shape and geometric characteristics of the building: floor plan dimensions, net and gross floor areas, floor plan blueprints, if any, number of floors, floor height, and total height regularity in floor plan and height

- $\quad$ information on the main structural system of the building

- $\quad$ information on construction materials used

- $\quad$ information on the roof structure and cover.

Although the detailed selection of attributes for building description primarily seeks to cover as many buildings as possible with a particular typology, the ultimate goal is to assess as accurately as possible their expected earthquake vulnerability. Choosing attributes for building typologies description is a compromise in order to obtain typologies applicable at the broadest (global) level.

It is impossible to describe each building with all its structural and non-structural peculiarities, not only because of their number and diversity but also because of the different uncertainties related to the existence and accuracy of data on these characteristics.

For regional levels, a number of researchers adopt and propose research and typology procedures that are simpler and that exclude incomplete and / or unreliable data, data that is difficult to find or

data representing only gross variations of local construction features [5].

\subsection{A Structural Typology for the City of Osijek Exposure Model}

For buildings, the major component of earthquake risk is exposure. Physical damage caused by earthquake effects is expected in a particular area, so the exposure typology applied to this area should reflect the characteristics of the existing building stock. Adopting a typology should follow recognized methodologies and procedures that lead to improvements and further development of the typology.

Structural typology is a systematically assembled set of global building characteristics. It must enable a simple and clear definition of the typological class of each building on the basis of the observed structural characteristics. An ideal typology model is created by identifying recurring characteristics, analyzing similarities and changes in structural design, and documenting them. 
The basis for defining structural typologies of buildings for the exposure model of the city of Osijek is the prevailing types of existing buildings with their structural and other characteristics.

For the city of Osijek building exposure model, the structural systems of the existing buildings are classified according to EMS 98 and elaborated in the typologies shown in Table 8.

Table 8. Structural typologies for the building's stock in the city of Osijek.

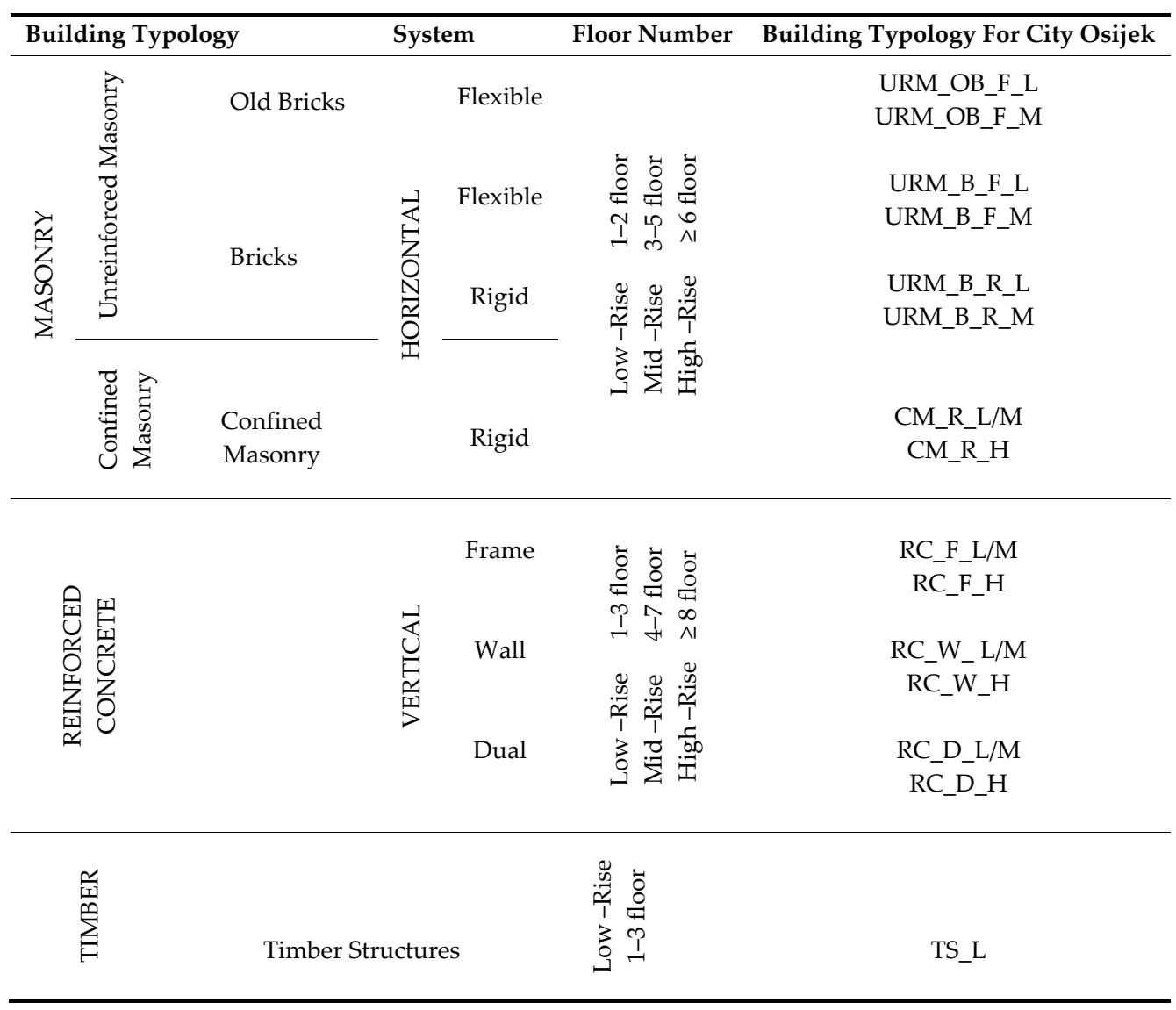

The adopted typology is generally close to the existing typologies (e.g., HAZUS, EMS-98) but more faithfully describes and reflects the condition of the building stock in the area for which it was created.

A comparison of the proposed typology for the city of Osijek and the existing typologies of HAZUS, EMS-98 is given in Table 9.

Table 9. Comparison of the HAZUS and EMS-98 typology with the proposed typology.

\begin{tabular}{ccc}
\hline HAZUS & EMS-98 & PROPOSED TYPOLOGY \\
\hline Masonry & Unreinforced Masonry & Unreinforced Masonry \\
\hline Unreinforced Masonry Bearing Walls (URM) & $\begin{array}{c}\text { Rubble Stone } \\
\text { Adobe (earth bricks) } \\
\text { Simple Stone } \\
\text { Massive Stone } \\
\text { UR Masonry (old brick) }\end{array}$ & $\begin{array}{c}\text { UR Masonry (old brick) } \\
\text { UR Masonry-RC floors }\end{array}$ \\
\hline Ueinforced/Confined Masonry & Reinforced/Confined Masonry & Confined Masonry \\
\hline RM Bearing walls with wood or metal deck diaphragms & Reinforced/Confined Masonry & Confined Masonry \\
RM Bearing walls with precast concrete diaphragms & Reinforced Concrete & Reinforced Concrete \\
\hline Reinforced Concrete & Frame in Reinforced Concrete \\
Concrete Moment Frame & Shear Walls & Frame \\
Concrete Shear Walls & Wall \\
Concrete Frame with Unreinforced Masonry Infill Walls & Dual & \\
\hline
\end{tabular}


The typologies shown in Table 9 do not differ in terms of defining basic structural types of buildings, but only in different approaches to defining individual sub-structural types.

Determining typologies for a particular area not only means a more specific classification of the observed stock of buildings in the area, but also a more accurate representation of the exposure and a more accurate assessment of earthquake damage.

\subsection{Proposal Vulnerability Classes for the City of Osijek Structural Typologies}

Damage is, according to Coburn et al. [45], the degree of loss of a particular risk element (structural element, building, human life, etc.) that is caused by a certain level of danger.

Predicting earthquake damage to buildings is a complex process whose implementation cannot be realized without the existence of an exposure model.

The expected damage level to new buildings, which have been designed according to modern earthquake-resistant building regulations, can be said to be predefined. In such buildings, low-intensity earthquakes should not cause damage, medium-intensity earthquakes should not cause structural damage, and strong earthquakes should not destroy them despite the possibility of significant damage.

Calculating the damage to older buildings is a more complex process not only because they are not built according to earthquake-resistance regulations, but also because the quality of the used materials is questionable (due to aging), and therefore the residual resistance and load-bearing capacity is also questionable.

For the adopted design typologies for the city of Osijek exposure model, the vulnerability classes in accordance with EMS_98 were proposed and are shown in Tables 10 and 11.

Table 10. Proposed vulnerability classes for masonry buildings.

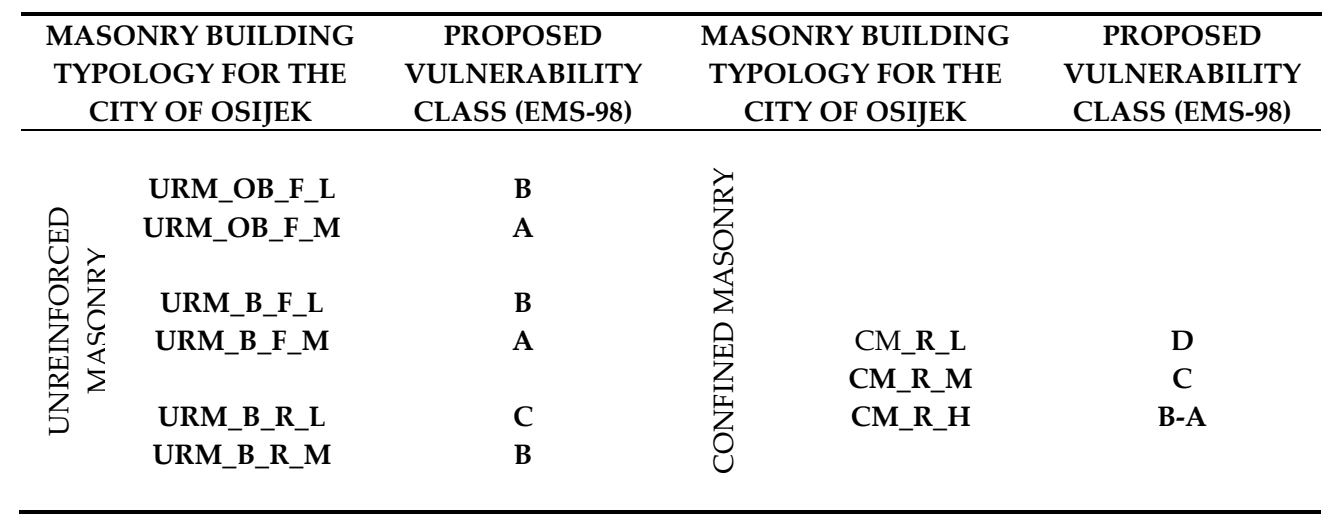

Table 11. Proposed vulnerability classes for reinforced concrete buildings.

\begin{tabular}{cccc}
\hline $\begin{array}{c}\text { RC BUILDING } \\
\text { TYPOLOGY FOR THE } \\
\text { CITY OF OSIJEK }\end{array}$ & $\begin{array}{c}\text { PROPOSED } \\
\text { VULNERABILITY } \\
\text { CLASS (EMS-98) }\end{array}$ & $\begin{array}{c}\text { RC BUILDING } \\
\text { TYPOLOGY FOR THE } \\
\text { CITY OF OSIJEK }\end{array}$ & $\begin{array}{c}\text { PROPOSED } \\
\text { VULNERABILITY } \\
\text { CLASS (EMS-98) }\end{array}$ \\
\hline RC_F_L & E & & \\
RC_F_M & D & RC_D_L & E \\
RC_F_H & C & RC_D_M & D \\
RC_W_L & EC_D_H & C \\
RC_W_M & E & RC_H & \\
RC_W_H & C & & \\
\hline
\end{tabular}

Note: These classes are intended for RC buildings with moderate earthquake-resistant design. For RC buildings without earthquake-resistant design, the assigned vulnerability class should be the first or second one lower. 
Identifying the seismic vulnerability of existing building stocks is a fundamental task for establishing guidelines and priorities in a long-term strategy for the prevention and reduction of earthquake losses [5,36,55-57].

\subsection{Processing and Displaying Data from the Osijek Database Using QGIS}

The purpose and ultimate goal of developing an exposure model for the City of Osijek is to make the data collected useful for planning for the prevention of possible earthquakes and other disasters and to make it simple and accessible for wider use. The ability to visualize, add new data, and modify existing ones are the criteria that an exposure model with such targets should possess. We used the Quantum-Geographic Information System (QGIS) to accomplish this.

QGIS is a computer system that can collect, store, analyze and display geo-referenced data. It can also be applied in dynamic spatial analysis of buildings and other related activities, such as rapid assessment of post-earthquake losses and / or planning of remediation [58].

For a characteristic block of buildings from the Osijek database, the distribution of buildings with respect to the structural system, floor structure, plan and vertical regularity of the building, position of the building in the block and the number of floors is shown in Figures 5-7 using QGIS. (Figures 5-7)

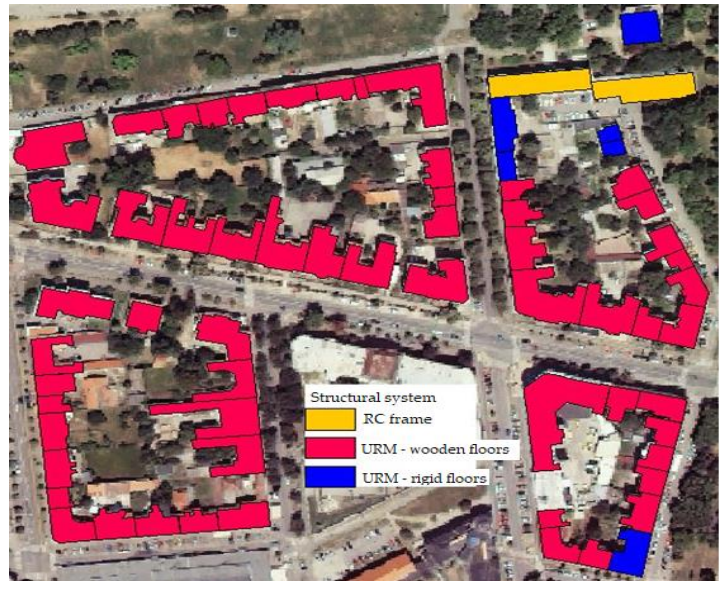

(a)

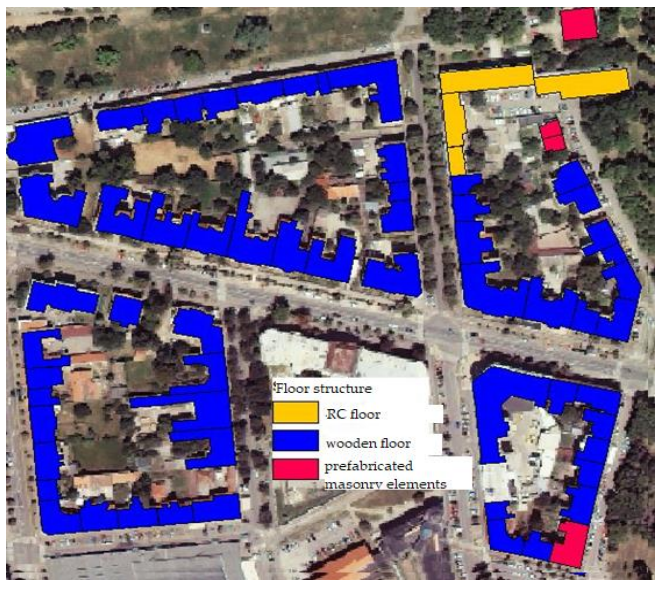

(b)

Figure 5. Characteristic block of buildings from the database: (a) structural system, (b) floor structure.

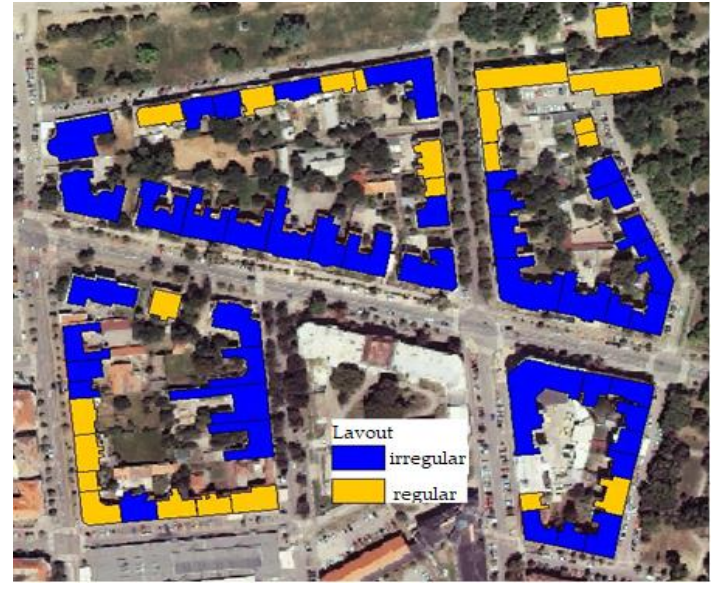

(a)

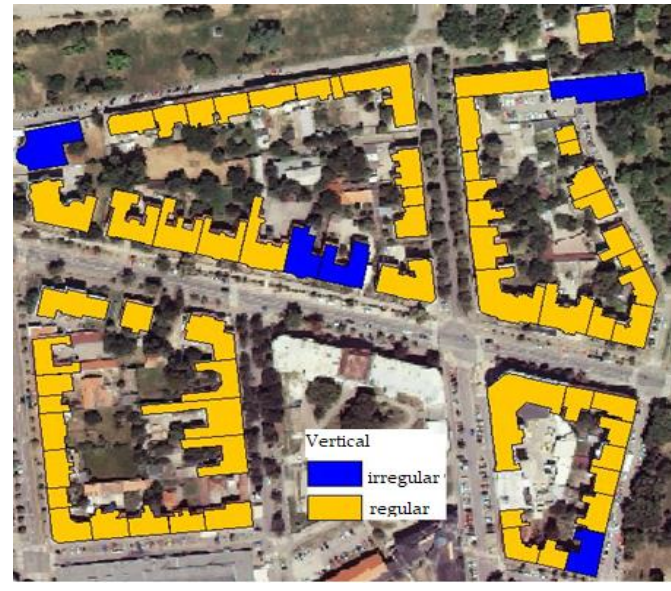

(b)

Figure 6. Characteristic block of buildings from the database: (a) plan(layout) regularities, (b) vertical regularities. 


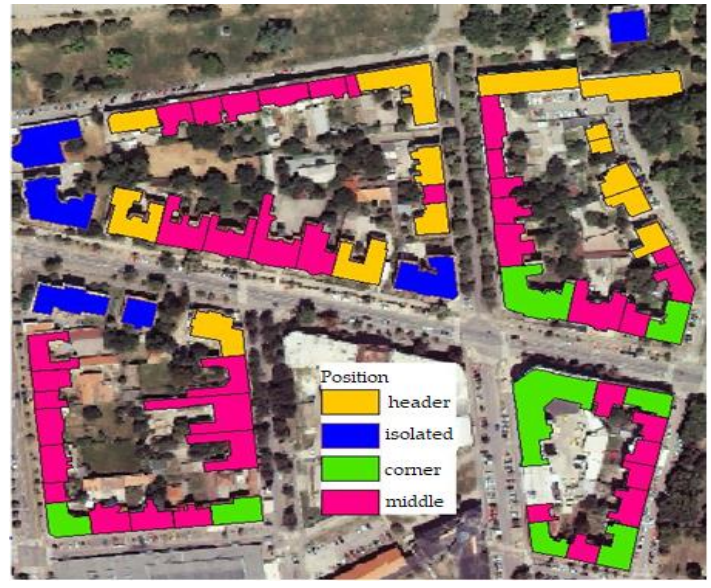

(a)

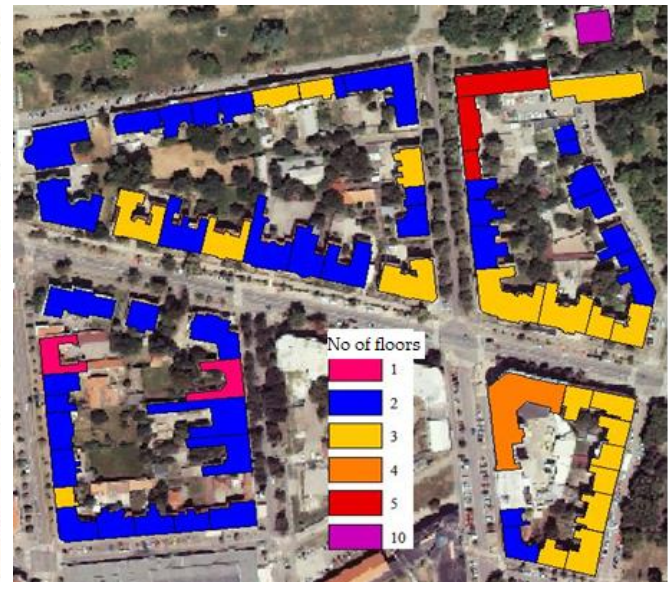

(b)

Figure 7. Characteristic block of buildings from the database: (a) position of the building in the block, (b) number of floors.

\section{Conclusions}

The importance of building exposure models is beyond doubt, as they not only help to quickly predict and estimate the damage to buildings and losses, but also help to understand the impact of natural disasters on people's lives.

Throughout the data collection stages, a large number of building attributes can be observed and recorded, however, this does not mean that the attributes that will fully capture the properties of the building stock have been selected. Often, simplified taxonomies that discard most of the important information, are used. In order to examine the overall earthquake performance of buildings through earthquake risk assessment, building exposure models must include a sufficient range of attributes that allow accurate descriptions of structures and possess the ability to classify them in compliance with the proposed taxonomies.

In developing the exposure model of the city of Osijek, a three-step methodology was applied. In the first step, the necessary attributes of the buildings are identified, which are then collected in-situ, subsequently evaluated, and synthesized. In the second step, the classification rules are defined and the structural typologies adopted, and in the third step, these typologies are assigned to individual buildings.

The process of exposure modeling is determined by several important guidelines: to focus on the most relevant features of buildings, to use not the available but the verified and reliable data, and to enable the replacement of existing data with higher quality and higher resolution data as they become available in the future.

The aim of the performed study is not to provide a detailed analysis of buildings, because this kind of analysis for the whole city/country would require multi-decadal, extensive research and considerable financial resources. The study presents an expert, technical assessment of the building stock, of limited (because of the possible subjectivity) but sufficiently usable accuracy, on the basis of which decision-makers can take more preventative measures to mitigate the consequences of possible catastrophic events.

The intent of the creators of this building exposure model is to make it usable, ready to be upgraded and further developed, and publicly available.

Even when they are not exposed to catastrophic events and when they are designed and built according to regulations, buildings can still be demolished for many reasons which are found only after the demolition: poor performance, poor quality of materials, aging of materials, etc. 
The existence of a proposed building stock exposure model can serve to predict and/or avoid such scenarios and is crucial for establishing guidelines and priorities in a long-term prevention strategy and mitigating losses caused by the catastrophic events that cannot be avoided or prevented.

The platform for this work is an ongoing macro-study, and the results obtained can be used to provide preliminary insight into the reliability of the results obtained and the issues discussed in general. We believe that this exposure model can be considered as a promising basis for conducting earthquake and other natural disaster vulnerability assessments.

Final conclusions and recommendations on the conducted survey are possible after the completion of the database development and implementation of the vulnerability calculation for the observed area and comparison of their results with the existing ones.

Author Contributions: Conceptualization, M.H.-N. and G.P.; methodology, M.H.-N., G.P. and B.B.; validation M.H.-N., G.P. and B.B.; formal analysis M.H.-N., G.P. and B.B.; investigation: M.H.-N., G.P., B.B. and Ž.J.; recources M.H.-N., G.P., B.B. and Ž.J.; writing—original draft preparation: M.H.-N., G.P., B.B. and and Ž.J.; final writing-review and editing: M.H.-N., G.P. and B.B. All authors have read and agreed to the published version of the manuscript.

Funding: This research received no external funding.

Conflicts of Interest: The authors declare no conflict of interest.

\section{References}

1. Dell'Acqua, F.; Gamba, P.; Jaiswal, K. Spatial aspects of building and population exposure data and their implications for global earthquake exposure modeling. Nat. Hazards 2013, 68, 1291-1309. [CrossRef]

2. Nikoo, M.; Ramezani, F.; Hadzima-Nyarko, M.; Nyarko, E.K.; Nikoo, M. Flood-routing modeling with neural network optimized by social-based algorithm. Nat. Hazards 2016, 82, 1-24. [CrossRef]

3. Alizadeh, M.; Alizadeh, E.; Asadollahpour Kotenaee, S.; Shahabi, H.; Beiranvand Pour, A.; Panahi, M.; Bin Ahmad, B.; Saro, L. Social Vulnerability Assessment Using Artificial Neural Network (ANN) Model for Earthquake Hazard in Tabriz City, Iran. Sustainability 2018, 10, 3376. [CrossRef]

4. Preciado, A.; Alejandro Ramirez-Gaytan, A.; Salido-Ruiz, R.A.; Caro-Becerra, J.L.; Lujan-Godinez, R. Earthquake risk assessment methods of unreinforced masonry structures: Hazard and vulnerability. Earthq. Struct. 2015, 9, 719-733. [CrossRef]

5. Uva, G.; Sanjust, C.A.; Casolo, S.; Mezzina, M. The ANTAEUS Project for the Regional Vulnerability Assessment of the Current Building Stock in Historical Centres. Int. J. Archit. Herit. Conserv. Anal. Restor. 2017, 11, 20-43.

6. Brzev, S.; Scawthorn, C.; Charleson, A.W.; Allen, L.; Greene, M.; Jaiswal, K.; Silva, V. GEM Building Taxonomy Version 2.0. GEM Technical Report 2013-02 v1.0.0; GEM Foundation: Pavia, Italy, 2013.

7. Grigoratos, J.; Monteiro, R.; Ceresa, P.; Di Meo, A.; Faravelli, M.; Borzi, B. Crowdsourcing Exposure Data for Seismic Vulnerability Assessment in Developing Countries. J. Earthq. Eng. 2018. [CrossRef]

8. USGS (2017). Earthquake catalogue for all earthquakes with $\mathrm{M}_{\mathrm{w}} \geq 2.5$ in the period 1900-2017 for the geographic region between $40.5^{\circ} \mathrm{N}$ and $47.5^{\circ} \mathrm{N}$, and $12.5^{\circ} \mathrm{E}$ and $24.5^{\circ} \mathrm{E}$. Available online: https: //earthquake.usgs.gov/earthquakes/search/1 (accessed on 23 February 2017).

9. Hrvatski zavod za norme (2011): HRN EN 1998-1:2011/NA:2011, Eurocode 8: Design of structures for earthquake resistance-Part 1: General rules, seismic actions and rules for buildings-National Annex. Available online: https://www.scribd.com/doc/186137599/nHRN-EN-1998-1-2011-NA (accessed on 20 December 2019).

10. Todorovska, M.I.; Al Rjoub, Y. Effects of rainfall on soil-structure system frequency: Examples based on poroelasticity and a comparison with full-scale measurements. Soil Dyn. Earthq. Eng. 2006, 26, 708-717. [CrossRef]

11. Trifunac, M.D.; Todorovska, M.I. Nonlinear soil response-1994 Northridge California earthquake. J. Geotech. Eng. 1996, 122, 725-735. [CrossRef]

12. Trifunac, M.D.; Todorovska, M.I. Nonlinear soil response as a natural passive isolation mechanism-The 1994 Northridge California earthquake. Soil Dyn. Earthq. Eng. 1998, 17, 41-51. [CrossRef] 
13. Trifunac, M.D.; Hao, T.Y.; Todorovska, M.I. On recurrence of site-specific response. Soil Dyn. Earthq. Eng. 1999, 18, 569-592. [CrossRef]

14. Lee, V.W.; Manić, M.I.; Bulajić, B.Đ.; Herak, D.; Herak, M.; Trifunac, M.D. Microzonation of Banja Luka for performance-based earthquake-resistant design. Soil Dyn. Earthq. Eng. 2015, 78, 71-88. [CrossRef]

15. Lee, V.W.; Trifunac, M.D.; Bulajić, B.Đ.; Manić, M.I.; Herak, D.; Herak, M.; Dimov, G. Seismic microzoning in Skopje, Macedonia. Soil Dyn. Earthq. Eng. 2017, 98, 166-182. [CrossRef]

16. Lee, V.W.; Trifunac, M.D.; Bulajić, B.Đ.; Manić, M.I.; Herak, D.; Herak, M.; Dimov, G.; Gičev, V. Seismic microzoning of Štip in Macedonia. Soil Dyn. Earthq. Eng. 2017, 98, 54-66. [CrossRef]

17. Lee, V.W.; Trifunac, M.D.; Bulajić, B.Đ.; Manić, M.I.; Herak, D.; Herak, M. Seismic microzoning of Belgrade. Soil Dyn. Earthq. Eng. 2017, 97, 395-412. [CrossRef]

18. Bulajić, B.Đ.; Bajić, S.; Stojnić, N. The effects of geological surroundings on earthquake-induced snow avalanche prone areas in the Kopaonik region. Cold Reg. Sci. Technol. 2018, 149, 29-45. [CrossRef]

19. Bulajić, B.Đ.; Manić, M.I.; Lađinović, Đ. Effects of shallow and deep geology on seismic hazard estimates-A case study of pseudo-acceleration response spectra for the north-western Balkans. Nat. Hazards 2013, 69, 573-588. [CrossRef]

20. Lee, V.W.; Trifunac, M.D.; Bulajić, B.Đ.; Manić, M.I. A preliminary empirical model for frequency-dependent attenuation of Fourier amplitude spectra in Serbia from the Vrancea earthquakes. Soil Dyn. Earthq. Eng. 2016, 83, 167-179. [CrossRef]

21. Lee, V.W.; Trifunac, M.D.; Bulajić, B.Đ.; Manić, M.I. Preliminary empirical scaling of pseudo relative velocity spectra in Serbia from the Vrancea earthquakes. Soil Dyn. Earthq. Eng. 2016, 86, 41-54. [CrossRef]

22. Croatian Bureau of Statistics. Census of Population, Households and Apartments 2011, Population by Citizenship, Ethnicity, Religion and Mother Tongue; Statistical Reports; Croatian Bureau of Statistics: Zagreb, Croatia, 2011.

23. Network of European Research Infrastructures for Earthquake Risk Assessment and Mitigation (NERA). Report D7.2 State of the Knowledge of Building Inventory Data in Europe, EUCENTRE; NERA: New York, NY, USA, 2011.

24. Antičević, A.; Hadzima-Nyarko, M.; Rabi, A. Seismic vulnerability of kindergarten buildings in the city of Osijek. In Proceedings of the 4th Conference-International Scientific Symposium, Economy of Eastern Croatia-Vision and Development, Osijek, Croatia, 21-23 May 2015.

25. Ivandić, N.; Hadzima-Nyarko, M.; Štefić, T. Seismic vulnerability of primary schools in the city Osijek. In Proceedings of the 4th Conference-International Scientific Symposium, Economy of Eastern Croatia-Vision and Development, Osijek, Croatia, 21-23 May 2015.

26. Hadzima-Nyarko, M.; Lešić, M.; Morić, D. Seismic Vulnerability Assessment for Residential Buildings in Osijek, Croatia. In Proceedings of the 16th World Conference of Earthquake Engineering, Santiago, Chile, 9-13 January 2017.

27. Galista, M.; Hadzima-Nyarko, M. Assessing seismic risk in Retfala Nova. Electron. J. Faculty Civil Eng. OSIJEK-E-GFOS 2015, 6, 50-61. [CrossRef]

28. Pavić, G.; Hadzima-Nyarko, M.; Plaščak, I.; Pavić, S. Seismic Vulnerability Assessment of Historical Unreinforced Masonry Buildings in Osijek using Capacity Spectrum Method. Acta Physica Polonica A 2019, 135, 1138-1141. [CrossRef]

29. Pavić, G.; Bulajić, B.; Hadzima-Nyarko, M. The Vulnerability of Buildings from the Osijek Database. Front. Built Environ. 2019, 5, 66. [CrossRef]

30. Meli, R.; Alcocer, S. Implementation of Structural Earthquake Mitigation Programs in Developing Countries. Nat. Hazards Rev. 2004, 5, 29-39. [CrossRef]

31. Dugoročna strategija za poticanje ulaganja u obnovu nacionalnog fonda zgrada Republike Hrvatske (in English: The Long-Term Strategy for Encouraging Investments in the Restoration of the National Building Stock of the Republic of Croatia). Available online: https://www.menea.hr/wp-content/uploads/2018/08/ Dugorocna.strategija.2017-nacrt.pdf (accessed on 20 December 2019).

32. Pittore, M.; Haas, M.; Megalooikonomou, K.G. Risk-Oriented, Bottom-Up Modeling of Building Portfolios with Faceted Taxonomies. Front. Built Environ. 2018, 4, 41. [CrossRef]

33. Abrahamczyk, L.; Schwarz, J.; Langhammer, T.; Genes, M.C.; Bikçe, M.; Kaçin, S.; Gülkan, P. Seismic risk assessment and mitigation in the Antakya-Maras region (SERAMAR): Empirical studies on the basis of EMS-98. Earthq. Spect. 2013, 29, 683-704. [CrossRef] 
34. Tyagunov, S.; Stempniewski, L.; Grünthal, G.; Wahlström, R.; Zschau, J. Vulnerability and risk assessment for earthquake-prone cities. In Proceedings of the 13th World Conference on Earthquake Engineering (13 WCEE), Vancouver, Canada, 1-6 August 2004; pp. 1-6.

35. Jaiswal, K.; Wald, D.; Porter, K. A global building inventory for earthquake loss estimation and risk management. Earthq. Spect. 2010, 26, 731-748. [CrossRef]

36. Kircher, C.A.; Whitman, R.V.; Holmes, W.T. HAZUS earthquake loss estimation methods. Nat. Hazards Rev. 2006, 7, 45-59. [CrossRef]

37. Grünthal, G.M.; Roger, M.W.; Schwarz, J.; Stucchi, M. Cahiers du Centre Européen de Géodynamique et de Séismologie. Available online: https://ci.nii.ac.jp/ncid/BA4375586X?1=en (accessed on 20 December 2019).

38. Kesete, Y.; Peng, J.; Gao, Y.; Shan, X.; Davidson, R.A.; Nozick, L.K.; Kruse, J. Modeling insurer-homeowner interactions in managing natural disaster risk. Risk Anal. 2014, 34, 1040-1055. [CrossRef]

39. Tzitzikas, Y. Faceted Taxonomy-Based Sources; Springer: Heidelberg, Germany, 2009.

40. SYNER-G: Systemic Seismic Vulnerability and Risk Assessment of Complex Urban, Utility, Lifeline Systems and Critical Facilities: Methodology and Applications; Pitilakis, K.; Franchin, P.; Khazai, B.; Wenzel, H. (Eds.) Springer: Heidelberg, Germany, 2014; Available online: https://www.springer.com/gp/book/9789401788342 (accessed on 24 January 2020).

41. Applied Technology Council. Earthquake Damage Evaluation Data for California, ATC-13; Applied Technology Council: Redwood City, CA, USA, 1985; p. 492.

42. FEMA. Rapid Visual Screening of Buildings for Potential Seismic Hazards: A Handbook, FEMA 154; Federal Emergency Management Agency(FEMA): Washington, WA, USA, 1988.

43. Grünthal, G. (Ed.) European Macroseismic Scale 1998 (EMS-98). Cahiers du Centre Européen de Géodynamique et de Séismologie 15; Centre Européen de Géodynamique et de Séismologie: Luxembourg, 1998; Available online: https://ci.nii.ac.jp/ncid/BA4375586X?l=en (accessed on 28 January 2020).

44. World Housing Encyclopedia (WHE). Earthquake Engineering Research Institute and the International Association for Earthquake Engineering. Available online: www.world-housing.net (accessed on 20 December 2019).

45. Coburn, A.; Spence, R. Earthquake Protection, 2nd ed.; John Wiley \& Sons: Chichester, UK, 2002.

46. FEMA. HAZUS-MH MR4 Technical Manual; Federal Emergency Management Agency (FEMA): Washington, WA, USA, 2003.

47. Gunel, M.H.; Ilgin, H.E. A Proposal for the Classification of Structural Systems of Tall Buildings. Build. Environ. 2007, 42, 2667-2675. [CrossRef]

48. Lee, W.V.; Pomonis, A.; So, E.; Spence, R. Existing Building Stock Classification in the Cambridge Earthquake Impact Database (CEQID); Global Earthquake Consequences Database, GEM Foundation: Pavia, Italy, 2011.

49. Jaiswal, K.S.; Wald, D.J. Creating a Global Building Inventory for Earthquake Loss Assessment and Risk Management, U.S. Geological Survey Open-File Report 2008-1160; U.S. Geological Survey: Reston, VA, USA, 2008; p. 103.

50. SYNER-G (2011), D3.1-Fragility Functions for Common RC Building Types in Europe, WP3-Fragility Functions of Elements at Risk, Systemic Seismic Vulnerability and Risk Analysis for Buildings, Lifeline Networks and Infrastructures Safety Gain. Available online: http://www.vce.at/SYNER-G/files/dissemination/ deliverables.html (accessed on 28 January 2020).

51. De Stefano, M.; Pintucchi, B. A review of research on seismic behaviour of irregular building structures since 2002. Bull Earthq. Eng. 2008, 6, 285-308. [CrossRef]

52. Lavan, O.; de Stefano, M. Seismic Behaviour and Design of Irregular and Complex Civil Structures; Springer: Heidelberg, Germany, 2013.

53. Behnam, B.; Shojaei, F. A Risk Index for Mitigating Earthquake Damage in Urban Structures. In Integrating Disaster Science and Management: Global Case Studies in Mitigation and Recovery; Samui, P., Kim, D., Ghosh, C., Eds.; Elsevier: Amsterdam, The Netherlands, 2018.

54. Gonzáles Herrera, R.; Gómez Soberon, C. Influence of Plan Irregularity of Buildings. In Proceedings of the 14th World Conference on Earthquake Engineering, Beijing, China, 12-17 October 2008.

55. Hadzima-Nyarko, M.; Pavić, G.; Lešić, M. Seismic vulnerability of old confined masonry buildings in Osijek, Croatia. Earthq. Struct. 2016, 11, 629-648. [CrossRef]

56. Hadzima-Nyarko, M.; Morić, D.; Pavić, G.; Mišetić, V. Spectral Functions of Damage Index (DI) for Masonry Buildings with Flexible Floors. Tech. Gaz. 2018, 25, 181-187. 
57. Işik, E.; Kutanis, M. Performance based assessment for existing residential buildings in Lake Van basin and seismicity of the region. Earthq. Struct. 2015, 9, 893-910. [CrossRef]

58. Zhai, Y.; Chen, S.; Ouyang, Q. GIS-Based Seismic Hazard Prediction System for Urban Earthquake Disaster Prevention Planning. Sustainability 2019, 11, 2620. [CrossRef]

(C) 2020 by the authors. Licensee MDPI, Basel, Switzerland. This article is an open access article distributed under the terms and conditions of the Creative Commons Attribution (CC BY) license (http://creativecommons.org/licenses/by/4.0/). 